\title{
Determination of ammonia and hydrogen sulfide emissions from a commercial dairy farm with an exercise yard and the health-related impact for residents
}

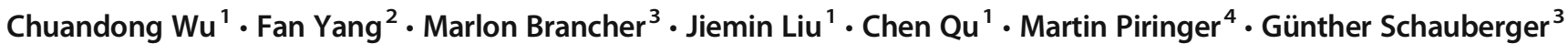

Received: 8 March 2020 / Accepted: 22 June 2020 / Published online: 30 June 2020

(C) The Author(s) 2020

\begin{abstract}
Airborne emissions from concentrated animal feeding operations (CAFOs) have the potential to pose a risk to human health and the environment. Here, we present an assessment of the emission, dispersion, and health-related impact of ammonia and hydrogen sulfide emitted from a 300-head, full-scale dairy farm with an exercise yard in Beijing, China. By monitoring the referred gas emissions with a dynamic flux chamber for seven consecutive days, we examined their emission rates. An annual hourly emission time series was constructed on the basis of the measured emission rates and a release modification model. The health risk of ammonia and hydrogen sulfide emissions around the dairy farm was then determined using atmospheric dispersion modeling and exposure risk assessment. The body mass-related mean emission factors of ammonia and hydrogen sulfide were $2.13 \mathrm{~kg} \mathrm{a}^{-1} \mathrm{AU}^{-1}$ and $24.9 \mathrm{~g} \mathrm{a}^{-1} \mathrm{AU}^{-1}$, respectively (one animal unit ( $\mathrm{AU}$ ) is equivalent to $500 \mathrm{~kg}$ body mass). A log-normal distribution fitted well to ammonia emission rates. Contour lines of predicted hourly mean concentrations of ammonia and hydrogen sulfide were mainly driven by the meteorological conditions. The concentrations of ammonia and hydrogen sulfide at the fence line were below $10 \mu \mathrm{g} \mathrm{m}^{-3}$ and $0.04 \mathrm{\mu g} \mathrm{m}^{-3}$, respectively, and were 2-3 orders of magnitude lower than the current Chinese air quality standards for such pollutants. Moreover, the cumulative non-carcinogenic risks (HI) of ammonia and hydrogen sulfide were 4 orders of magnitudes lower than the acceptable risk levels $(\mathrm{HI}=1)$. Considering a health risk criterion of $1 \mathrm{E}-4$, the maximum distance from the farm fence line to meet this criterion was nearly $1000 \mathrm{~m}$ towards north-northeast. The encompassed area of the contour lines of the ambient concentration of ammonia is much larger than that of hydrogen sulfide. However, the contour lines of the ammonia health risk are analogous to those of hydrogen sulfide. In general, the ammonia and hydrogen sulfide emissions from the dairy farm are unlikely to cause any health risks for the population living in the neighborhood.
\end{abstract}

Keywords Emission $\cdot$ Ammonia $\cdot$ Hydrogen sulfide $\cdot$ Health risk $\cdot$ Dispersion model $\cdot$ Dairy farm

Responsible Editor: Gerhard Lammel

Chuandong $\mathrm{Wu}$

wuchuandong@ustb.edu.cn

Fan Yang

yangfan19870117@126.com

Marlon Brancher

Marlon.Brancher@vetmeduni.ac.at

Jiemin Liu

liujm@ustb.edu.cn

Chen Qu

quchen5626@163.com

Martin Piringer

martin.piringer@zamg.ac.at
Günther Schauberger

Gunther.Schauberger@vetmeduni.ac.at

1 School of Chemistry and Biological Engineering, University of Science and Technology Beijing, Beijing 100083, China

2 Beijing Municipal Research Institute of Environmental Protection, Beijing 100037, China

WG Environmental Health, Unit for Physiology and Biophysics, University of Veterinary Medicine, Vienna, Austria

4 Department of Environmental Meteorology, Central Institute of Meteorology and Geodynamics, Vienna, Austria 


\section{Background}

Concentrated animal feeding operations (CAFOs), such as dairy and cattle farms, have been extensively developed in recent decades to meet peoples' demands for meat and dairy products (Hu et al. 2017). Gaseous compounds emitted from dairy farms have evoked increasing social and environmental concerns (Jahne et al. 2015; Wang et al. 2018). Accordingly, residents are concerned with potential health risks due to gas emissions from dairy farms. The airborne emissions from dairy feedlots mainly consist of greenhouse gases (methane, nitrous oxides, and carbon dioxide) and pollutant gases (ammonia $\left(\mathrm{NH}_{3}\right)$, hydrogen sulfide $\left(\mathrm{H}_{2} \mathrm{~S}\right)$, volatile fatty acids (VFAs), phenols, and others) (Hales et al. 2015; Hales et al. 2012; Lee et al. 2018; Wang et al. 2018). Previous studies have shown that livestock production contributes extensively to $\mathrm{NH}_{3}$ and $\mathrm{H}_{2} \mathrm{~S}$ emissions (Feilberg et al. 2017; Maasikmets et al. 2015).

Emissions of noxious gases such as $\mathrm{NH}_{3}$ and $\mathrm{H}_{2} \mathrm{~S}$ could be worrying due to their malodorous and hazardous properties and are responsible for the acidification of ecosystems and the formation of secondary particulate matter (Maasikmets et al. 2018). Workers and neighbors of CAFOs such as dairy farms can be directly exposed to emitted noxious gases primarily through inhalation. Long-term exposure to these pollutants has been associated with potential health risks such as respiratory irritation and central nervous system damage (Jaars et al. 2018; Wu et al. 2018). Thus, there is a need to evaluate the potential health risks induced by noxious gases emitted from CAFOs such as dairy farms.

Several methods exist for the determination of gas emissions from CAFOs (Liu et al. 2017). Dynamic flux chamber is a direct measurement method. It has been widely used for the calculation of gas emission rates from passive surface sources (Parker et al. 2013b). Such measurements of the emission rates are needed, for instance, to estimate ambient concentrations at receptor points surrounding the emission source using dispersion models (Brancher et al. 2017; Schauberger et al. 2012). However, limited systematic studies assessing the ambient concentrations and the related health risk caused by noxious gas emissions from dairy farms can be found in the literature. Several of them have focused on odor, $\mathrm{NH}_{3}$, VFAs, and phenols (Hales et al. 2012; Lee et al. 2018; Rørvang et al. 2017), but $\mathrm{H}_{2} \mathrm{~S}$ emissions can be more odorous and toxic due to its lower odor threshold value and reference concentration (RfC) value for chronic inhalation exposure. Studies on the assessment of noxious gas emissions from dairy farms with a large exercise yard are still limited (Keck 1997). Moreover, the related studies were mainly conducted in developed countries, whereas the dispersion and risks of $\mathrm{NH}_{3}$ and $\mathrm{H}_{2} \mathrm{~S}$ emitted from dairy farms in China have not yet been well studied.

In this study, we present an assessment of the emission and the related human health risks of $\mathrm{NH}_{3}$ and $\mathrm{H}_{2} \mathrm{~S}$ from a dairy farm in Beijing, China. The assessment is based on flux measurements, emission modeling, and atmospheric dispersion modeling. The emission rates of $\mathrm{NH}_{3}$ and $\mathrm{H}_{2} \mathrm{~S}$ were measured with a dynamic flux chamber for seven consecutive days and then detrended to eliminate the impact of the meteorological predictors using a release modification factor $R_{0}$. Moreover, the $\mathrm{NH}_{3}$ and $\mathrm{H}_{2} \mathrm{~S}$ ambient concentrations were predicted using a steady-state Gaussian plume model (AERMOD modeling system) and were used to assess the related non-carcinogenic health risks to residents around the dairy farm.

\section{Methods}

\section{Dairy farm}

This study was conducted at a dairy farm in Beijing, China $(40.10 \mathrm{~N}, 116.16 \mathrm{E})$. The site is located about $30 \mathrm{~km}$ north from the center of Beijing and it is surrounded by three villages within a $1 \mathrm{~km}$ radius (Fig. 1). The detailed description of the site, the surroundings of the farm, and the topography of the area have been presented in a previous study (Wu et al. 2019). Briefly, the terrain around the farm is mostly flat, and the land is mainly used for farming. The dairy farm has an area of $\sim 0.67 \mathrm{~km}^{2}$, comprised of feedlot pens, feed mill, slurry treatment workshop, and administrative office. The farm has three feedlot pens with a total area of about $42,000 \mathrm{~m}^{2}$. The feedlot pen consists of an exercise yard with a brick floor and a cowshed with a solid concrete floor. The cowshed consists of two specular sections with a manger and a row of free stalls, separated by a central aisle (Fig. 1). About 300 cows are raised in the feedlot pens. The average body mass of the cows is $600 \mathrm{~kg}$ or $1.2 \mathrm{AU}(1 \mathrm{AU}=500 \mathrm{~kg})$, and the daily milk production per cow is in the range of $27-33 \mathrm{~kg} \mathrm{cow}^{-1}$ day $^{-1}$. The feedstuff consists of $20 \mathrm{~kg}$ corn silage, $11 \mathrm{~kg}$ concentrate (maize, bean pulp, bran, etc.), $11 \mathrm{~kg}$ of alfalfa, gramineae, cotton seeds, and soy flours for each cow per day. The manure is cleaned from the feeding area using a scraper every day and stored in a vacant cowshed near the feedlot pens. The slurry from the feeding area and the milking parlor is disposed in a slurry treatment workshop. The exhaust gas emitted from the slurry treatment workshop is treated by biofiltration and absorption, so gaseous pollutants were assumed for this process.

\section{$\mathrm{NH}_{3}$ and $\mathrm{H}_{2} \mathrm{~S}$ emissions}

The $\mathrm{NH}_{3}$ and $\mathrm{H}_{2} \mathrm{~S}$ emissions, $E_{N}$ and $E_{H}$ (in $\mathrm{mg} \mathrm{s}^{-1}$ ), respectively, from the dairy farm were determined following two 
Fig. 1 Location and surrounding of the dairy farm. a Feedlot pens (including cowshed and exercise yard); b silage storage; $\mathrm{c} 1$ village $1 ; \mathrm{c} 2$ village $2, \mathrm{c} 3$ village 3 ; pentagram stands for the sampling site

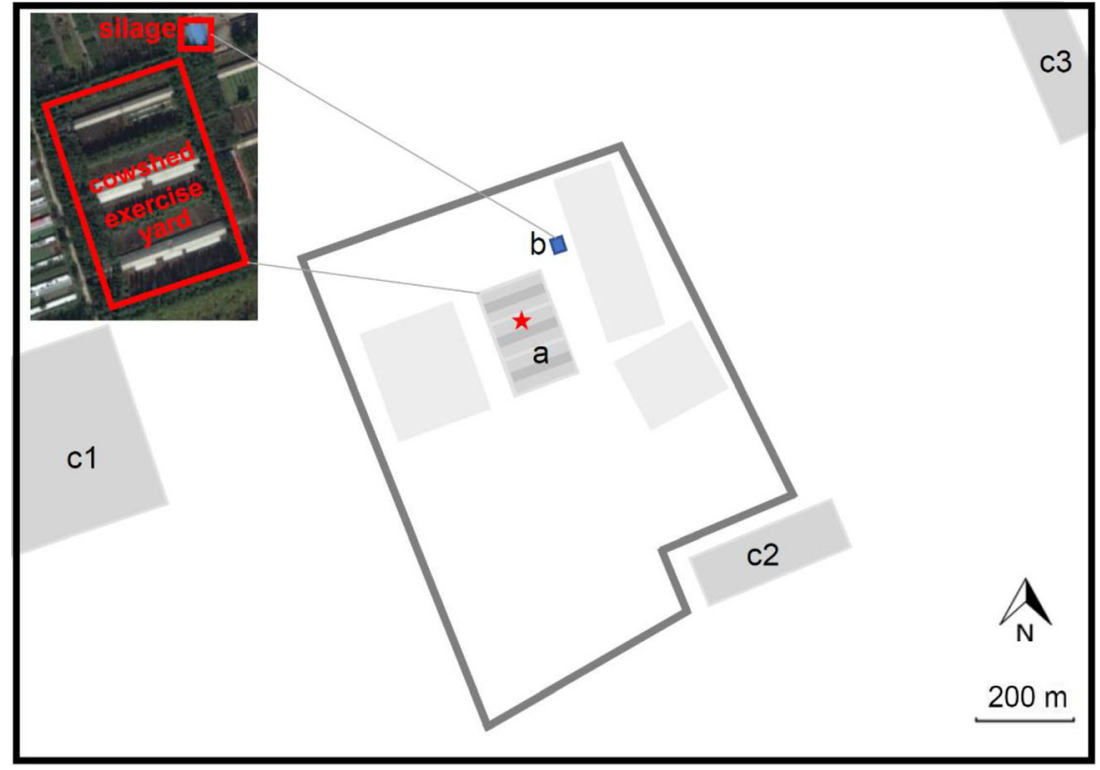

methods: (i) by the measurement of the area-specific emission rate using a flux chamber and (ii) by a release modification model that predicts the release variation through meteorological parameters. In doing so, the emission rate is given as an hourly time series.

The sampling site was located in the middle of the feedlot pen surface of the dairy farm (Fig. 1). Air samples were collected during daylight hours (8:00 am to 7:00 pm local time) in May 2017 for seven consecutive days. The samples were collected with a dynamic flux chamber, which has been widely used in previous studies dealing with the determination of odor emission rates (Gallego et al. 2014; Parker et al. 2013a; Prata et al. 2016). The flux chamber consists of a cylindrical enclosure that is a half-dome with a diameter of $0.4 \mathrm{~m}$ and an overall height of $0.25 \mathrm{~m}$. The internal volume and area of the flux chamber were $30 \mathrm{~L}$ and $0.12 \mathrm{~m}^{2}$, respectively.

To determine the $\mathrm{NH}_{3}$ and $\mathrm{H}_{2} \mathrm{~S}$ emissions, the flux chamber was placed on the feedlot pen surface with the skirt buried approximately $5 \mathrm{~cm}$ deep into the topsoil to ensure a good seal around the base of the chamber. Nitrogen flow was swept through the flux chamber using a perforated plastic y-tube configured as a loop along the interior circumference. The nitrogen flow was controlled by a flow meter. Before each sampling, the flux chamber was equilibrated for $24 \mathrm{~min}$ with a flow rate of $5 \mathrm{~L} \mathrm{~min}^{-1}$. This procedure is needed to avoid sampling errors derived from pressure disturbances generated by the disposition of the sampling device. The nitrogen flow rate was adjusted to $2 \mathrm{~L} \mathrm{~min}^{-1}$ when air sampling initiated.

$\mathrm{NH}_{3}$ and $\mathrm{H}_{2} \mathrm{~S}$ emitted from the covered surface were mixed with the nitrogen and flowed out of the chamber to the impingers. $\mathrm{NH}_{3}$ and $\mathrm{H}_{2} \mathrm{~S}$ in a known volume of the mixed gas were then trapped bubbling into impingers which contained $10 \mathrm{~mL}$ of sulfuric acid and $10 \mathrm{~mL}$ of cadmium sulfate solution, respectively. Concentrations of $\mathrm{H}_{2} \mathrm{~S}$ and $\mathrm{NH}_{3}$ in the absorption solutions were measured by analyzing them with UV/vis spectrophotometer according to the national standard method in China (Wu et al. 2017). Detailed procedures regarding the analysis and relevant quality assurance are similar to those reported in our previous work ( $\mathrm{Wu}$ et al. 2017). During the seven consecutive sampling days, a total of 42 samples were collected. The meteorological conditions (air temperature, relative humidity, and wind speed at the sampling site with a height of $1.5 \mathrm{~m}$ and the air temperature inside the flux chamber) during the sampling campaign were measured with a thermo-anemometer (EXTECH, DK5158 45158, USA).

On the basis of the measurements, the area-specific emission factor $e_{\mathrm{A} \text {,meas }}\left(\mathrm{g} \mathrm{a}^{-1} \mathrm{~m}^{-2}\right)$ was calculated from the mean $\mathrm{NH}_{3}$ and $\mathrm{H}_{2} \mathrm{~S}$ concentrations, $C_{\mathrm{N}}$ and $C_{\mathrm{H}}$ (in $\mathrm{mg} \mathrm{m}^{-3}$ ), respectively, the volume flow rate $v=0.12 \mathrm{~m}^{3} \mathrm{~h}^{-1}$, and the area $A_{\text {flux }}=0.12 \mathrm{~m}^{2}$ of the flux chamber. Using the available area per animal place of $A=140 \mathrm{~m}^{2}$ and a body mass of $M=$ 1.2 AU, the emission factor was also related to the body mass $e_{\mathrm{M} \text {,meas }}\left(\mathrm{kg} \mathrm{a}^{-1} \mathrm{AU}^{-1}\right)$ and the animal place $e_{\mathrm{AP}, \text { meas }}\left(\mathrm{kg} \mathrm{a}^{-1}\right.$ $\left.\mathrm{AP}^{-1}\right)$.

Meteorological conditions modify the release of $\mathrm{NH}_{3}$ and $\mathrm{H}_{2} \mathrm{~S}$ (the meteorological data on the farm will be shown in the "Results" section). This effect was taken into account by a release modification factor $R$, which was calculated using a regression model developed for a commercial naturally ventilated dairy farm (Hempel et al. 2016). The meteorological predictors of the regression model are air temperature $T$ $\left({ }^{\circ} \mathrm{C}\right)$, relative humidity $F(\%)$, and wind speed $W\left(\mathrm{~m} \mathrm{~s}^{-1}\right)$. The annual and diurnal change of emissions is taken into account by the Julian day DOY (day of the year) and the time of the day $t(\mathrm{~h})$ and by the use of sinusoidal functions. The 
impact of the wind direction was not considered herein due to the open space of the exercise yard. The hourly release modification factor $R$ reads as

$$
\begin{aligned}
\log R= & c_{1} \sin \left(\frac{2 \pi}{365} D O Y\right)+c_{2} \cos \left(\frac{2 \pi}{365} D O Y\right) \\
& +c_{3} \sin \left(\frac{2 \pi}{24} t\right)+c_{4} \cos \left(\frac{2 \pi}{24} t\right)+c_{5} T \\
& +c_{6} F+c_{7} W
\end{aligned}
$$

with the coefficients of the regression model $c_{1}-\mathrm{c}_{7}$ according to Hempel et al. (2016).

To eliminate the bias due to the meteorological parameters during the measurements, reference emission factors $e_{\mathrm{x}, 0}$ were determined. They were related to $x$ equal to the area $A$, the animal place AP, and the body mass $M$. These emission factors were calculated by the release modification factor $R_{\text {meas }}$ to eliminate the impact of the predictors of the emission by $e_{\mathrm{x}, 0}=$ $e_{\mathrm{x}, \text { meas }} / R_{\text {meas }}$ with the meteorological parameters during the field measurements.

The specific emission factors for the year $2017 e_{\mathrm{A}, 17}$, $e_{\mathrm{AP}, 17}$, and $e_{\mathrm{M}, 17}$ were calculated using the reference specific emission factors $e_{\mathrm{A}, 0}, e_{\mathrm{AP}, 0}$, and $e_{\mathrm{M}, 0}$ and the time series of the hourly release modification factor $R_{17}$ using hourly mean values of meteorological parameters (temperature, relative humidity, and wind speed) for 2017 (8760 h).

\section{Modeled $\mathrm{NH}_{3}$ and $\mathrm{H}_{2} \mathrm{~S}$ concentrations in ambient air}

Based on dispersion calculations, the impact of the dairy farm emissions on air quality, as well as the health risk of these emissions for residents, can be assessed. Here, the AERMOD modeling system was used to predict $\mathrm{NH}_{3}$ and $\mathrm{H}_{2} \mathrm{~S}$ ambient concentrations. In essence, the modeling system contains three modules: (i) the AERMOD dispersion model itself, (ii) the AERMET meteorological processor, and (iii) the AERMAP terrain processor. Versions 18081 of these modules were herein used. AERMOD is considered an advanced steady-state Gaussian plume model because it integrates atmospheric dispersion based on planetary boundary layer turbulence structure and scaling concepts. It incorporates the Monin-Obukhov similarity theory to estimate the stability of the atmospheric boundary layer in a continuous manner (Cimorelli et al. 2005; EPA 2018; Perry et al. 2005).

The primary inputs to AERMOD were the $\mathrm{NH}_{3}$ and $\mathrm{H}_{2} \mathrm{~S}$ emissions (on an hourly basis as previously described) and meteorological data. Regarding the latter, the selection of an appropriate meteorological station that best represents the area surrounding the farm has been recently presented in $\mathrm{Wu}$ et al. (2019). For brevity, the reader is referred to this work for a complete description of the meteorological input data. In short, the meteorological station Haidian has been selected for the investigation. A 1-year time series of meteorological observations for 2017 from that station has been used.

The modeling protocol followed the current default regulatory options set in the US Guideline on Air Quality Models (EPA 2017). Time series of ambient pollutant concentrations were calculated on a highly resolved nested grid placed in a model domain with a spatial resolution of $5 \times 5 \mathrm{~km}$. Receptors were not placed within the dairy farm boundary, meaning that only the emission impact instantly from the farm fence line has been considered. A total of 6297 receptors at $1.5 \mathrm{~m}$ above ground level were defined for this receptor grid network. The feedlot pens were treated as an area source at ambient temperature with a release height of $5 \mathrm{~cm}$. A digital elevation model for the model domain was built using the AERMAP terrain processor with terrain data in SRTM1 (resolution of about $30 \mathrm{~m}$ ). Within the model domain, elevations from near $40 \mathrm{~m}$ to no more than $70 \mathrm{~m}$ above sea level occur. When processing meteorological data through AERMET, the AERSURFACE utility in its version 13016 was used to specify the surface characteristics (surface roughness length, albedo, and Bowen ratio). Furthermore, the adjusted surface friction velocity technique was considered. This option has the aim of addressing model performance concerns for stably stratified atmospheric boundary layers under low wind speeds (Pandey and Sharan 2019; Qian and Venkatram 2011). Background pollutant concentrations were not considered so that only the dairy farm emissions are reflected in the $\mathrm{NH}_{3}$ and $\mathrm{H}_{2} \mathrm{~S}$ ambient concentration estimates. The results are judged conservative because deposition (mainly for $\mathrm{NH}_{3}$ ) is treated as negligible and chemical transformations (for $\mathrm{NH}_{3}$ and $\mathrm{H}_{2} \mathrm{~S}$ ) are not accounted for. Different averaging times (hourly, daily, monthly, and annual) were investigated.

\section{Determination of the health risk due to the $\mathrm{NH}_{3}$ and $\mathrm{H}_{2} \mathrm{~S}$ exposure}

In the case of noxious gases emitted from the dairy farm, inhalation is mainly considered the primary route of human exposure in the present study. Thus, the non-carcinogenic effects of $\mathrm{NH}_{3}$ and $\mathrm{H}_{2} \mathrm{~S}$ are assessed by combining the people's inhalation exposure to compounds in the ambient air with toxicological parameters and the methodology recommended by EPA (2009).

The inhalation exposure to compounds was calculated by estimating the annual mean exposure concentration EC for each receptor exposed to pollutants via inhalation. ECs are time-weighted average concentrations which were derived from the predicted annual mean of the ambient concentrations $C_{\mathrm{a}}$ for $\mathrm{NH}_{3}$ and $\mathrm{H}_{2} \mathrm{~S}$ and a weighting factor $f_{\mathrm{T}}$ taking into account the exposure time, as shown in the following equation (EPA 2009):

$\mathrm{EC}=C_{\mathrm{a}} f_{\mathrm{T}}$ 
with EC for each compound, and the predicted annual mean concentration $C_{\mathrm{a}}$ in $\mu \mathrm{g} \mathrm{m}^{-3}$. The weighting factor for the exposure $f_{\mathrm{T}}$ gives the portion of time for 20 years when exposure can be expected. The weighting factor was calculated for an exposure of $24 \mathrm{~h}$ per day, 350 days per year, which gives $f_{\mathrm{T}}=0.959$ (Bari and Kindzierski 2017; Wu et al. 2018). For non-carcinogenic effects, the health risk is expressed by the hazard index HI. Moreover, people are typically exposed through inhalation to a mixture of the gaseous compounds rather than individual pollutants. Thus, a cumulative noncarcinogenic HI was calculated to account for the simultaneous exposure to $\mathrm{NH}_{3}$ and $\mathrm{H}_{2} \mathrm{~S}$ (EPA 2009; Mustafa et al. 2017; Wu et al. 2018). The HI was calculated by means of the exposure concentration EC and the reference concentration $\mathrm{RfC}$ value for chronic inhalation exposure as $\mathrm{HI}=\mathrm{EC} / \mathrm{RfC}$. The reference concentration for $\mathrm{NH}_{3}$ is $\mathrm{RfC}=0.002 \mathrm{mg} \mathrm{m}^{-3}$; for $\mathrm{H}_{2} \mathrm{~S}$, it is $\mathrm{RfC}=0.5 \mathrm{mg} \mathrm{m}^{-3}$ (EPA 2009).

\section{Results}

The emission factor of ammonia and hydrogen sulfide was realized by a twofold strategy: (1) the emission factor $e$ was first determined directly from the measurements; (2) using the release modification factor $R$, the measurements were detrended to eliminate the impact of the predictors during the measurements, which gives the reference emission factor $e_{0}$.

Table 1 summarizes the statistics of the specific emission factor $e$, which is related to the emission area $A\left(\mathrm{~m}^{2}\right)$, the number of animal places AP (-) in the barn, and the body mass $M(\mathrm{AU})$. These three parameters define the activity value. For example, the emission rate $E$ can be calculated by the body mass-specific emission rate $e_{\mathrm{M}}$ and the activity value $M$ according to $E=e_{\mathrm{M}} M$. The reference specific emission factors $e_{0}$ were detrended by $R_{0}$. The specific emission factors $e_{\mathrm{A}}$,
$e_{\mathrm{AP}}$, and $e_{\mathrm{M}}$ are overestimated in relation to the reference specific emission factors $e_{\mathrm{A}, 0}, e_{\mathrm{AP}, 0}$, and $e_{\mathrm{M}, 0}$ by a factor of 4.23 for $\mathrm{NH}_{3}$ and 8.00 for $\mathrm{H}_{2} \mathrm{~S}$. The overestimation is primarily caused by the fact that the measurements were performed during periods which are characterized by higher emissions. The higher factor for $\mathrm{H}_{2} \mathrm{~S}$ can be explained because the measurements were taken only during noon with higher air temperatures. On the other hand, the $\mathrm{NH}_{3}$ measurements were also performed during daytime, which results in higher emissions due to higher animal activity.

A log-normal distribution can describe the empirical measurements. Figure 2 shows the body mass-specific emission factor $e_{\mathrm{M} \text {,meas }}$ for the field measurements and the body massspecific reference emission factor $e_{\mathrm{M}, 0}$ for $\mathrm{NH}_{3}$. The corresponding log-normal distributions for the two emission factors were calculated by the mean value and the standard deviation of the logarithmically transformed emission factors $e_{\mathrm{M} \text {,meas }}$ and $e_{\mathrm{M}, 0}$, respectively. The emission factor for $\mathrm{H}_{2} \mathrm{~S}$ was not graphically depicted because only 7 measurements are available. The fact that in most studies log-normal distributions of the emission rate are selected can be explained by the multiplicative modulation of the emission by several predictors (Brancher et al. 2020; Limpert and Stahel 2011; Limpert et al. 2001).

Table 2 shows the $\mathrm{NH}_{3}$ and $\mathrm{H}_{2} \mathrm{~S}$ emission factors for 2017 $e_{\mathrm{A}, 17}, e_{\mathrm{AP}, 17}$, and $e_{\mathrm{M}, \mathrm{a}}$, related to the area $A$, the animal place $\mathrm{AP}$, and the body mass $M$. The annual mean values were calculated by hourly meteorological observations of the Haidian station for 2017 (as shown in our previous work (Wu et al. 2019)).

The discrepancy between the annual mean values $e_{\mathrm{x}, 17}$ (Table 2) compared with the emission factors of the measuring period $e_{\mathrm{x}, \text { meas }}$ (Table 1) is caused by differences in the meteorological conditions, which are expressed by the release modification factor $R$. The air samples were only collected in May during daytime. Table 3 summarizes the differences between

Table 1 Measured specific emission factors and the corresponding reference emission factors

\begin{tabular}{|c|c|c|c|c|c|c|}
\hline & \multicolumn{3}{|c|}{ Measurements } & \multicolumn{3}{|c|}{ Reference values } \\
\hline & Area $e_{\mathrm{A} \text {,meas }}$ & Animal place $e_{\mathrm{AP} \text {,meas }}$ & Body mass $e_{\mathrm{M} \text {,meas }}$ & Area $e_{\mathrm{A}, 0}$ & Animal place $e_{\mathrm{AP}, 0}$ & Body mass $e_{\mathrm{M}, 0}$ \\
\hline $\mathbf{N H}_{3}$ & $\mathrm{~g} \mathrm{a}^{-1} \mathrm{~m}^{-2}$ & $\mathrm{~kg} \mathrm{a}^{-1} \mathrm{AP}^{-1}$ & $\mathrm{~kg} \mathrm{a}^{-1} \mathrm{AU}^{-1}$ & $\mathrm{~g} \mathrm{a}^{-1} \mathrm{~m}^{-2}$ & $\mathrm{~kg} \mathrm{a}^{-1} \mathrm{AP}^{-1}$ & $\mathrm{~kg} \mathrm{a}^{-1} \mathrm{AU}^{-1}$ \\
\hline Maximum & 61.6 & 8.63 & 7.19 & 21.53 & 3.01 & 2.51 \\
\hline Minimum & 4.2 & 0.58 & 0.49 & 0.80 & 0.11 & 0.09 \\
\hline Mean value & 18.3 & 2.56 & 2.13 & 5.76 & 0.81 & 0.672 \\
\hline $\mathrm{H}_{2} \mathrm{~S}$ & $\mathrm{mg} \mathrm{a}^{-1} \mathrm{~m}^{-2}$ & $\mathrm{~g} \mathrm{a}^{-1} \mathrm{AP}^{-1}$ & $\mathrm{~g} \mathrm{a}^{-1} \mathrm{AU}^{-1}$ & $\mathrm{mg} \mathrm{a}^{-1} \mathrm{~m}^{-2}$ & $\mathrm{~g} \mathrm{a}^{-1} \mathrm{AP}^{-1}$ & $\mathrm{~g} \mathrm{a}^{-1} \mathrm{AU}^{-1}$ \\
\hline Maximum & 295.9 & 41.4 & 34.5 & 40.04 & 5.61 & 4.67 \\
\hline Minimum & 134.5 & 18.8 & 15.7 & 10.11 & 1.42 & 1.18 \\
\hline Mean value & 213.3 & 29.9 & 24.9 & 24.65 & 3.45 & 2.88 \\
\hline
\end{tabular}

Measured specific emission factors $\left(e_{\mathrm{A} \text {,meas }}, e_{\mathrm{AP} \text {,meas }}\right.$, and $\left.e_{\mathrm{M} \text {,meas }}\right)$ : related to the emission area $A\left(\mathrm{~m}^{2}\right)$, the number of animal places AP (-) in the barn, and the body mass $M(\mathrm{AU})$. Corresponding reference emission factors $\left(e_{\mathrm{A}, 0}, e_{\mathrm{AP}, 0}\right.$, and $\left.e_{\mathrm{M}, 0}\right)$ : detrended by the release modification factor $R_{\mathrm{meas}}$ for $\mathrm{NH}_{3}$ and $\mathrm{H}_{2} \mathrm{~S}$, calculated for the meteorological parameters during the field measurements. Mean value: arithmetic mean value 


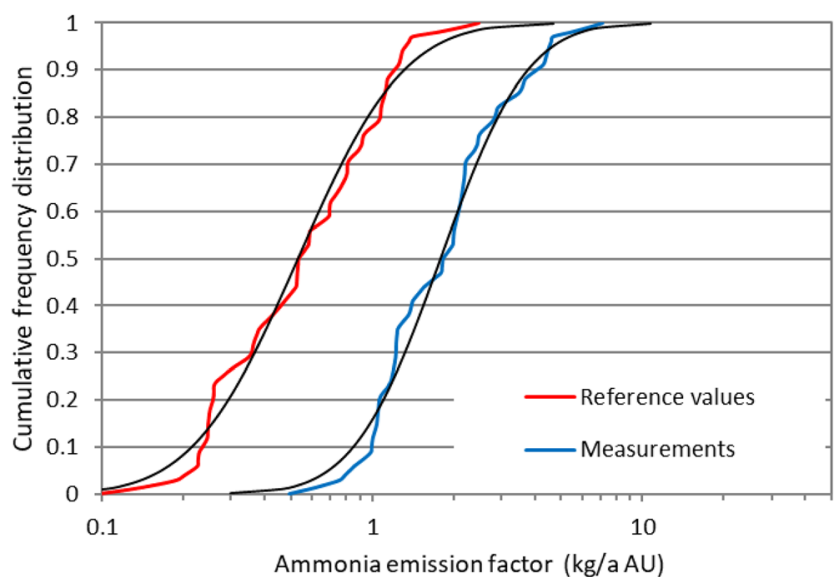

Fig. 2 Empirical cumulative distribution function of the measured body mass-specific emission factor $e_{\mathrm{M} \text {,meas }}\left(\mathrm{kg} \mathrm{a}^{-1} \mathrm{AU}^{-1}\right)$ and the body massspecific reference emission factor $e_{\mathrm{M}, 0}\left(\mathrm{~kg} \mathrm{a}^{-1} \mathrm{AU}^{-1}\right)$ for the $\mathrm{NH}_{3}$ emissions from the dairy farm for the field measurements. Black lines show the theoretical log-normal distributions. The mean value of the measured emission factor $e_{\mathrm{M} \text {,meas }}$ is $2.13 \mathrm{~kg} \mathrm{a}^{-1} \mathrm{AU}^{-1}$; the mean reference emission factor $e_{\mathrm{M}, 0}$ is $0.672 \mathrm{~kg} \mathrm{a}^{-1} \mathrm{AU}^{-1}$ (Table 1)

the meteorological parameters. The overestimation of $e_{\mathrm{x}, \text { meas }}$ was caused by the higher temperatures during the measurements in May compared with the annual mean temperature and due to the fact that the measurements were conducted during daytime with higher animal activity.

The hourly time series of $\mathrm{NH}_{3}$ emissions for 2017 shows a substantial variation over the year (Fig. 3). As previously mentioned, the air samples were collected during the warm season (May and only during daytime) which causes an overestimation of the emissions. This overestimation was eliminated by the use of the release modification factor for the period of the field measurements. A daily mean was also computed from the hourly values and overlaid in Fig. 3 to depict the annual daily pattern of the $\mathrm{NH}_{3}$ emissions.

Table 2 Statistics of the emission factors for 2017 of $\mathrm{NH}_{3}$ and $\mathrm{H}_{2} \mathrm{~S}$

\begin{tabular}{clll}
\hline \multicolumn{4}{c}{ Emission factors for 2017} \\
\cline { 2 - 4 } & ${\text { Area } e_{\mathrm{A}, 17}}$ & Animal place $e_{\mathrm{AP}, 17}$ & Body mass $e_{\mathrm{M}, 17}$ \\
\hline $\mathrm{NH}_{\mathbf{3}}$ & $\mathrm{g} \mathrm{a}^{-1} \mathrm{~m}^{-2}$ & $\mathrm{~kg} \mathrm{a}^{-1} \mathrm{AP}^{-1}$ & $\mathrm{~kg} \mathrm{a}^{-1} \mathrm{AU}^{-1}$ \\
Maximum & 100.2 & 14.0 & 11.7 \\
Minimum & 0.11 & 0.02 & 0.01 \\
Mean value & 8.49 & 1.19 & 0.99 \\
$\mathbf{H}_{\mathbf{2}} \mathbf{S}$ & $\mathrm{mg} \mathrm{a}^{-1} \mathrm{~m}^{-2}$ & $\mathrm{~g} \mathrm{a}^{-1} \mathrm{AP}^{-1}$ & $\mathrm{~g} \mathrm{a}^{-1} \mathrm{AU}^{-1}$ \\
Maximum & 429.3 & 60.1 & 50.1 \\
Minimum & 0.49 & 0.07 & 0.06 \\
Mean value & 36.40 & 5.10 & 4.25
\end{tabular}

The emission factors $\left(e_{\mathrm{A}, 17}, e_{\mathrm{AP}, 17}\right.$, and $e_{\mathrm{M}, 17}$, which were related to the emission area $A$, the animal place AP, and the body mass $M$.) were calculated based on the reference specific emission factors $e_{\mathrm{A}, 0}, e_{\mathrm{AP}, 0}$, and $e_{\mathrm{M}, 0}$ and the release modification factor $R_{17}$ for the year 2017 . Mean value is the arithmetic mean
Figure 4 shows the contour lines of first high hourly mean concentrations of $\mathrm{NH}_{3}$ around the dairy farm. Typically, the elongation of the contour lines tended to be greater in the prevailing winds, mainly driven by the frequency of wind directions. The maximum hourly concentrations for $\mathrm{NH}_{3}$ and $\mathrm{H}_{2} \mathrm{~S}$ were $13.2 \mu \mathrm{g} \mathrm{m}^{-3}$ and $0.056 \mu \mathrm{g} \mathrm{m}^{-3}$, respectively. The maximum distances for a $\mathrm{NH}_{3}$ concentration of $5 \mu \mathrm{g} \mathrm{m}$ is about $350 \mathrm{~m}$ towards north-northeast (NNE) and about $250 \mathrm{~m}$ towards southwest (SW). These maximum distances reach about $1300 \mathrm{~m}$ and $1200 \mathrm{~m}$, respectively, for the concentration of $2 \mu \mathrm{g} \mathrm{m}^{-3}$. For lower $\mathrm{NH}_{3}$ concentration of $1 \mu \mathrm{g} \mathrm{m}^{-3}$, the separation distances nearly doubled compared with that of $2 \mu \mathrm{g} \mathrm{m}^{-3}$, forming a larger encompassed area (the purple area in Fig. 4). Moreover, the concentration of $\mathrm{NH}_{3}$ at the fence line is in the range of $2 \mu \mathrm{g} \mathrm{m}^{-3}$ (NNE)-10 $\mu \mathrm{g} \mathrm{m}^{-3}$ (SW). These values are 2-3 orders of magnitude lower than the current emission standards in China $\left(1.5 \mathrm{mg} \mathrm{m}^{-3}\right)$ (GB14554 1993), and also far below the upcoming new version of the emission standards $\left(0.2 \mathrm{mg} \mathrm{m}^{-3}\right)$.

On the other hand, the contour lines of the first high hourly mean ambient concentrations of $\mathrm{H}_{2} \mathrm{~S}$ are shown in Fig. 5 . From a visual inspection of this figure, the shape of the encompassed area of $\mathrm{H}_{2} \mathrm{~S}$ is comparable with those of $\mathrm{NH}_{3}$. This is due to the fact that $\mathrm{NH}_{3}$ and $\mathrm{H}_{2} \mathrm{~S}$ levels around the dairy farm shared the same origin and dispersion pathway. The maximum distance for an $\mathrm{H}_{2} \mathrm{~S}$ concentration of $0.04 \mu \mathrm{g} \mathrm{m}^{-3}$ is about $150 \mathrm{~m}$ towards NNE. For a lower $\mathrm{H}_{2} \mathrm{~S}$ concentration of $0.02 \mu \mathrm{g} \mathrm{m}^{-3}$, the maximum separation distances are about $700 \mathrm{~m}$ towards NNE and $400 \mathrm{~m}$ towards SW. The concentration of $\mathrm{H}_{2} \mathrm{~S}$ at the fence line ranges from $0.02 \mu \mathrm{g} \mathrm{m}^{-3}$ to $0.04 \mu \mathrm{g} \mathrm{m}^{-3}$, which is three orders of magnitude lower than the current and the upcoming emission standards in China (0.06 $\mathrm{mg} \mathrm{m}^{-3}$ and $0.02 \mathrm{mg} \mathrm{m}^{-3}$, respectively) (GB14554 1993).

For the other averaging times investigated in this work (daily, monthly, and annual), it was observed that the impact of $\mathrm{NH}_{3}$ and $\mathrm{H}_{2} \mathrm{~S}$ emissions was even lower, so that the creation of contour maps was unnecessary.

From a toxicological point of view, the $\mathrm{NH}_{3}$ and $\mathrm{H}_{2} \mathrm{~S}$ exposure, described by ambient concentrations around the dairy farm, could pose potential health risks to nearby residents. Hence, the non-carcinogenic risks (quantified by $\mathrm{HI}$ ) of $\mathrm{NH}_{3}$ and $\mathrm{H}_{2} \mathrm{~S}$ were assessed according to the methodology recommended by the USEPA (EPA 2009). For this purpose, we considered the annual mean concentration calculated by the AERMOD dispersion model (Figs. 4 and 5). The outcomes are displayed in Figs. 6 and 7. Moreover, the cumulative noncarcinogenic risk (quantified by $\Sigma \mathrm{HI}$ ) was calculated to account for the simultaneous exposure to both $\mathrm{NH}_{3}$ and $\mathrm{H}_{2} \mathrm{~S}$ (Fig. 8). The contour lines of health risks of $\mathrm{NH}_{3}, \mathrm{H}_{2} \mathrm{~S}$, and $\sum$ HI stretch from south-southwest (SSW) to NNE. The shape of the contour lines is similar and is mainly driven by the distribution of wind directions. 
Table 3 Maximum, minimum, and mean values of the meteorological predictors used to calculate the emission factors both for the measuring period and for the year 2017

\begin{tabular}{|c|c|c|c|c|c|c|}
\hline & \multicolumn{2}{|l|}{ Temperature $T\left({ }^{\circ} \mathrm{C}\right)$} & \multicolumn{2}{|c|}{ Relative humidity $F(\%)$} & \multicolumn{2}{|c|}{ Wind speed $W\left(\mathrm{~m} \mathrm{~s}^{-1}\right)$} \\
\hline & Measuring period & Annual mean & Measuring period & Annual mean & Measuring period & Annual mean \\
\hline Maximum & 36.9 & 38.7 & 63 & 97 & 6.5 & 6.8 \\
\hline Minimum & 19.5 & -10.8 & 12 & 5 & 0.4 & 0.5 \\
\hline Mean & 28.0 & 11.4 & 30 & 42 & 3.1 & 1.7 \\
\hline
\end{tabular}
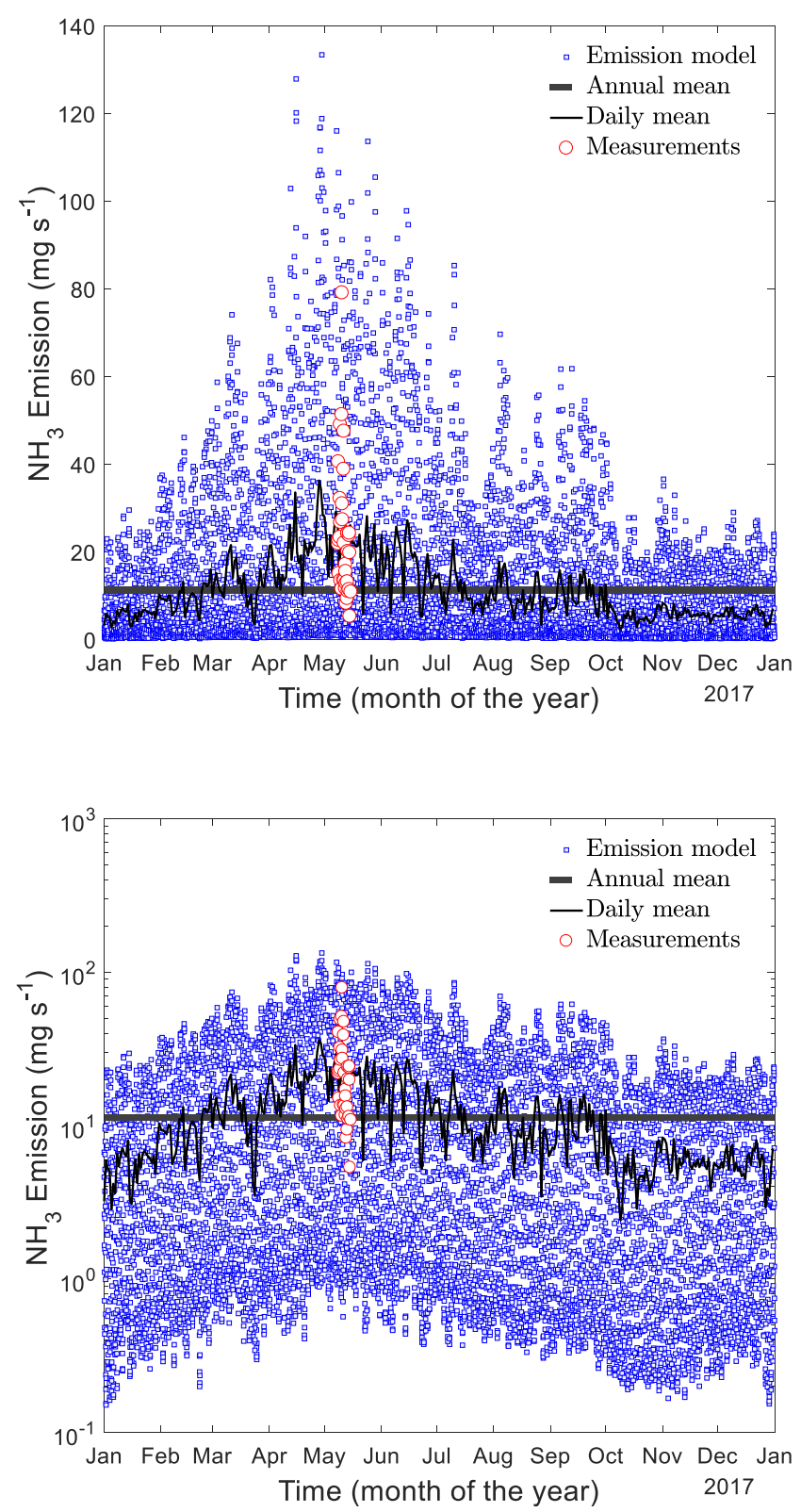

Fig. 3 Time course of the ammonia emission rate $E\left(\mathrm{mg} \mathrm{s}^{-1}\right)$ calculated by the body mass-specific emission factor $e_{\mathrm{M}, 0}=0.672 \mathrm{~kg} \mathrm{a}^{-1} \mathrm{AU}^{-1}$ and the total body mass inside the barn of $M=360 \mathrm{AU}$, calculated for the 2017 meteorological dataset of the Haidian station by the release modification factor $R_{17}$. The field measurements are shown in red. The annual mean value is $11.3 \mathrm{mg} \mathrm{s}^{-1}$ shown by the black line. Panel A is linearly, panel B logarithmically diagramed
In general, the $\mathrm{HI}$ of $\mathrm{NH}_{3}$ and $\mathrm{H}_{2} \mathrm{~S}$ around the dairy farm is quite low. The $\mathrm{HI}$ of $\mathrm{H}_{2} \mathrm{~S}$ is very close to that of $\mathrm{NH}_{3}$, although the ambient concentration of $\mathrm{H}_{2} \mathrm{~S}$ was far lower than that of $\mathrm{NH}_{3}$. The health-related impact posed by $\mathrm{H}_{2} \mathrm{~S}$ deserves more attention in similar facilities since the reference concentration (RfC) of $\mathrm{H}_{2} \mathrm{~S}\left(0.002 \mathrm{mg} \mathrm{m}^{-3}\right)$ is 250 times lower than that of $\mathrm{NH}_{3}\left(0.5 \mathrm{mg} \mathrm{m}^{-3}\right)$ (EPA 2009). From the perspective of cumulative risk, the $\sum \mathrm{HI}$ values near the fence line of the dairy farm were in the range of $3 \mathrm{E}-5-4 \mathrm{E}-4$. With the health risk criterion of $\mathrm{HI}=1 \mathrm{E}-4$, the maximum separation distances for the NNE and SSW wind directions are approximately $1000 \mathrm{~m}$ and $700 \mathrm{~m}$, respectively. For residents who are living in the three surrounding villages (villages 1-3, shown in Fig. 1), the cumulative carcinogenic risks are $3 \mathrm{E}-5,1 \mathrm{E}-5$, and $1 \mathrm{E}-5$, respectively. These HI values were 4 orders of magnitude lower than the acceptable risk levels $(\mathrm{HI}=1)$, indicating that the health risk from the ambient $\mathrm{NH}_{3}$ and $\mathrm{H}_{2} \mathrm{~S}$ around the dairy farm is low.

\section{Discussion}

Emissions from livestock facilities that keep animals both inside barns or in open space are commonly estimated by emission factors and the related activity values. The emission factors are mostly associated with the area which is available for the animals, animal place, or body mass, expressed in AU $(1 \mathrm{AU}=500 \mathrm{~kg})$. For dairy farms, the last two factors are closely related because the body mass of a cow is more or less $600 \mathrm{~kg}$ or 1.2 AU. The available area per animal shows much more variability, depending on the livestock keeping system. For cubicles, about $10 \mathrm{~m}^{2}$ is available for one animal (Baldini et al. 2016). Contrary, in our case, the area per animal is about $140 \mathrm{~m}^{2}$. For such a widespread range, the body mass-related emission factor or the animal place-related emission factor seems to be more appropriate for dairy farms.

It is well known that the emission of $\mathrm{NH}_{3}$ and $\mathrm{H}_{2} \mathrm{~S}$ of livestock farming is influenced by several predictors. The most important ambient predictors are air temperature, wind speed above the release surface, and relative humidity (Maasikmets et al. 2015; Schauberger et al. 2013). Other predictors are the time of the day as a proxy for animal activity. 


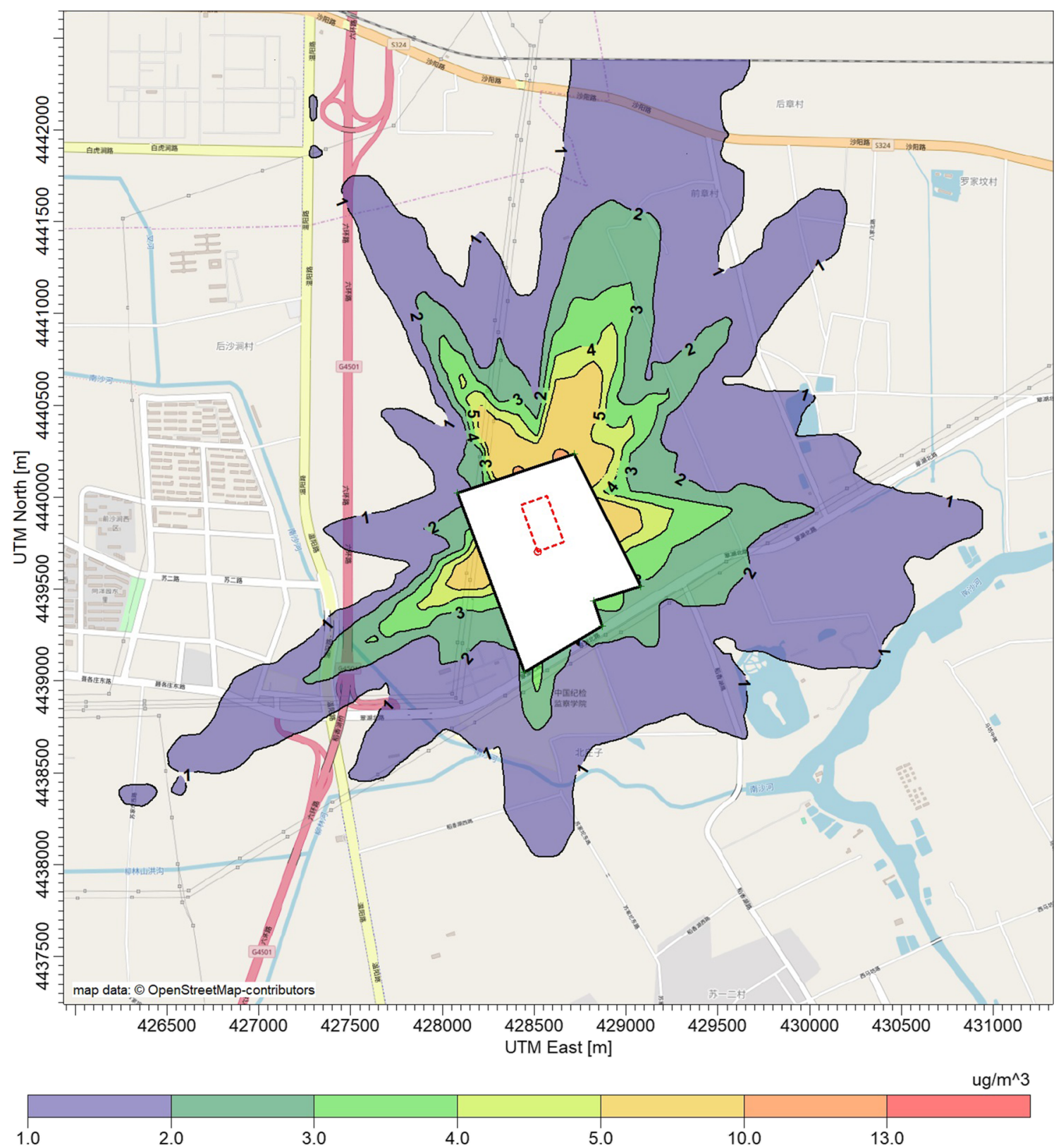

Fig. 4 Contour plot of hourly mean concentrations of ammonia in the surrounding area of the dairy farm. The black circle stands for the fence line of the farm, and the red rectangle stands for the feedlot pen areas

Lonsdale et al. (2017) reported that $\mathrm{NH}_{3}$ emissions from livestock feedlots show a strong diurnal cycle, peaking at midday. Yang et al. (2016) and Mukhtar et al. (2008) observed apparent seasonal variations in $\mathrm{NH}_{3}$ emissions from dairy feedlots. Joo et al. (2015) concluded that the $\mathrm{NH}_{3}$ emissions from dairy barns correlated fairly well with temperature $\left(R^{2}=0.29\right.$ to $0.51)$, but correlated moderately with wind speed $\left(R^{2}=0.01\right.$ to 0.46). Feilberg et al. (2017) reported that the concentration of $\mathrm{NH}_{3}$ in a cattle farm in summer is 1.9 times higher than that in winter, while for $\mathrm{H}_{2} \mathrm{~S}$, the discrepancy could be 14.6 times since the production of $\mathrm{H}_{2} \mathrm{~S}$ from, e.g., sulfate reduction is strongly reduced at low temperatures. Multiple linear regression models built by Wu et al. (2012) showed that wind speed
$(P<0.001)$ and air temperature $(P<0.001)$ influence ammonia emissions from dairy cattle buildings significantly. In the current study, a positive monocausal correlation trend was found between $\mathrm{NH}_{3}$ emission factors and both the ambient air temperature at the height of $1.5 \mathrm{~m}$ and the air temperature inside the flux chamber ( $r=0.59$ and 0.60 , respectively, $p<$ $0.001, n=35$ ). Based on continuous measurements of ammonia, it has been shown that indoor temperature, air velocity, and animal activity are the most relevant influencing factors that affect ammonia emission (Arogo et al. 2003; BlanesVidal et al. 2008; Flesch et al. 2009; Hayes et al. 2006; Huang and Guo 2017; Schauberger et al. 2013; Ye et al. 2011). 


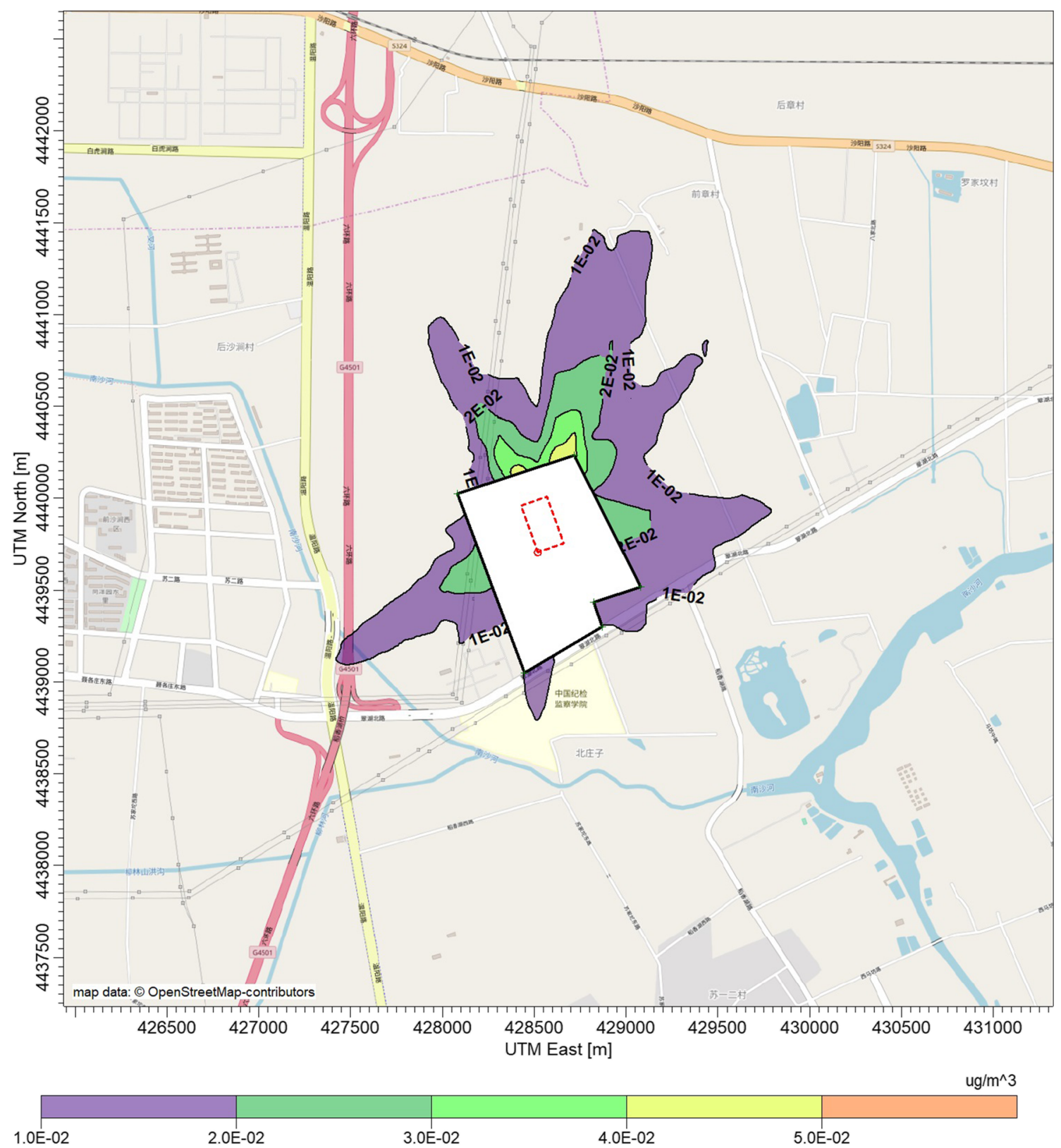

Fig. 5 Contour plot of hourly mean concentrations of hydrogen sulfide in the surrounding area of the dairy farm. The black circle stands for the fence line of the farm, and the red rectangle stands for the feedlot pen areas

The correlation between relative humidity and the $\mathrm{NH}_{3}$ emission rate in dairy farms is seen controversial. AdvientoBorbe et al. (2010) reported a poor correlation of $r=-0.025$ in a free-stall cow barn. Hempel et al. (2016) and Saha et al. (2014) addressed the significant effect of relative humidity on the $\mathrm{NH}_{3}$ emissions from a naturally ventilated dairy barn. The cause is complicated and needs further investigation. Ammonia is water-soluble and could be transformed into ammonium $\left(\mathrm{NH}_{4}{ }^{+}\right)$in humid air and thus affect the measurement of gaseous ammonia with infrared photo-acoustic analyzer (Saha et al. 2014). Hadlocon et al. (2014) concluded that high moisture content in the air might also cause cross-interference in the readings of the instrument, and the recommended acid trap method is as a reference for this condition. For confined livestock buildings and naturally ventilated barns, these parameters depend on the indoor climate, which can be simulated by appropriate models (Mikovits et al. 2019; Schauberger et al. 2000).

The impact of these predictors can be analyzed in two ways: (1) by a statistical approach, the impact is examined by regression models (e.g., Hempel et al. 2016; Saha et al. 2013). The major disadvantage of regression models is the limitation of the interpretation of the calculated regression coefficients; (2) by physical-orientated models, which open 
Fig. 6 Contour plot of the criterion for non-carcinogenic risk $\mathrm{HI}$ of ammonia in the surrounding area of the dairy farm. The farm fence line is depicted in the center of the plot

Fig. 7 Contour plot of the criterion for non-carcinogenic risk $\mathrm{HI}$ of hydrogen sulfide in the surrounding area of the dairy farm. The farm fence line is depicted in the center of the plot
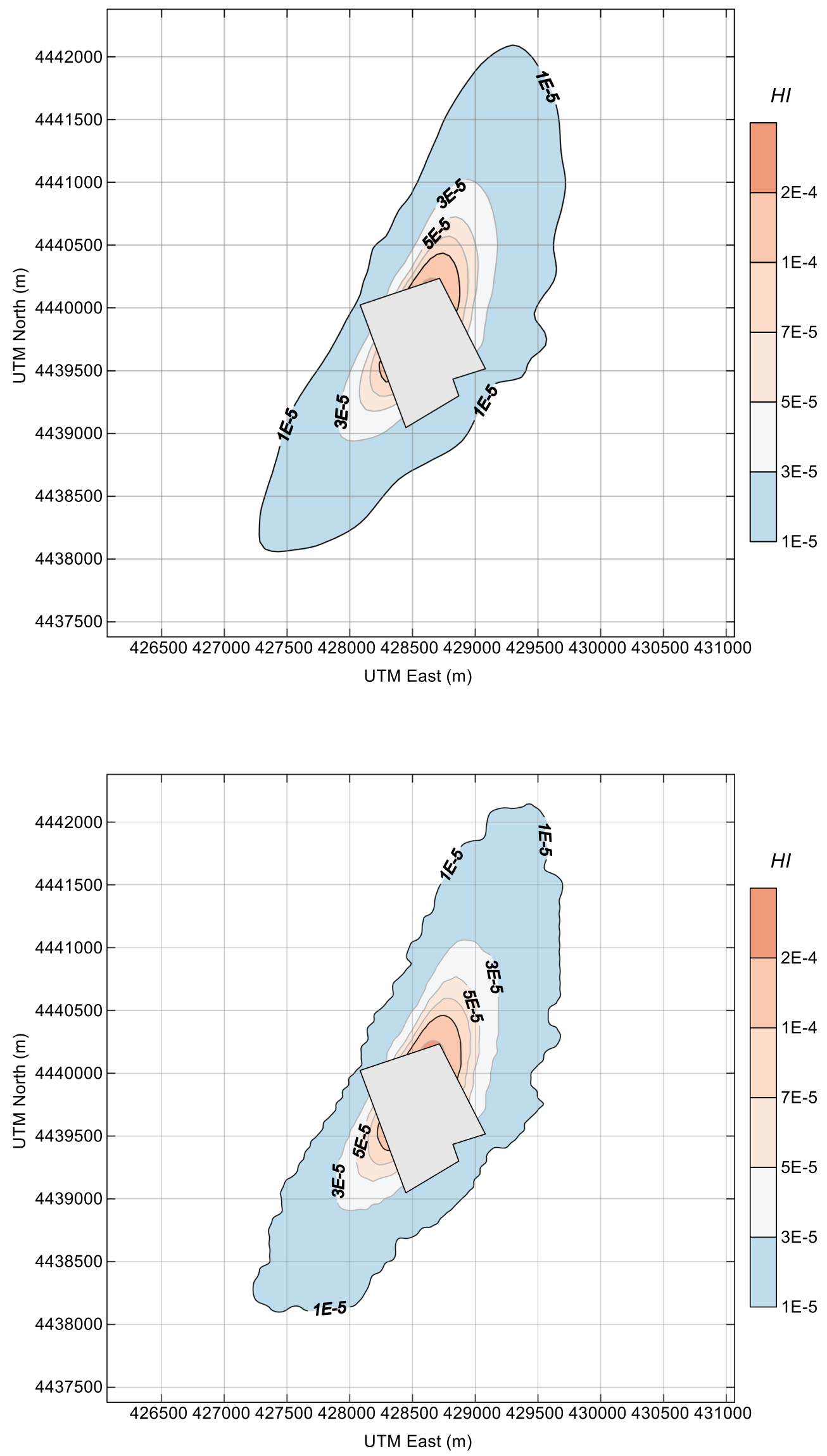
Fig. 8 Contour plot of the criterion for cumulative carcinogenic risk $\left(\sum \mathrm{HI}\right)$ of ammonia and hydrogen sulfide in the surrounding area of the dairy farm. The farm fence line is depicted in the center of the plot

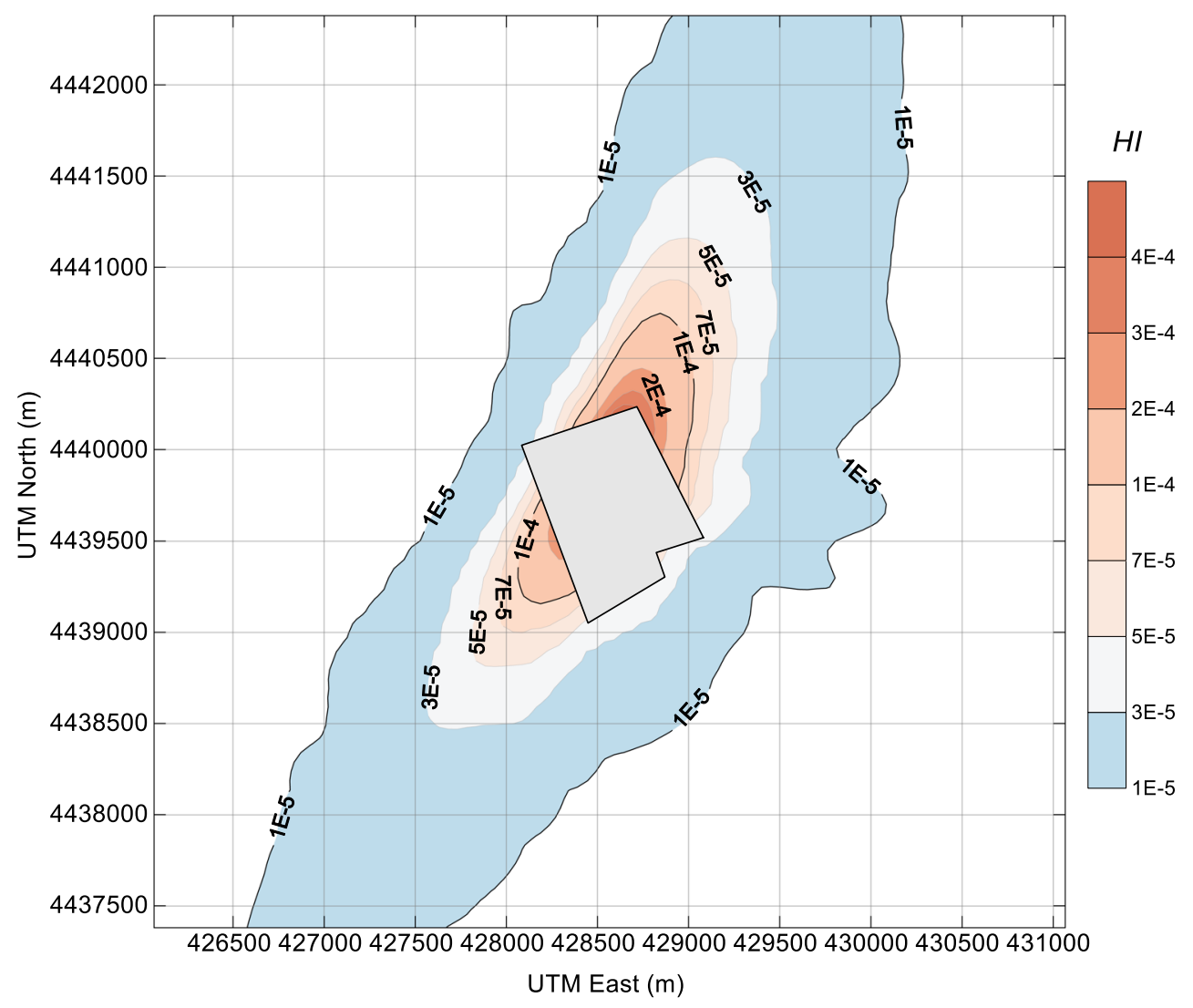

the opportunity to compare the regression model outputs with other investigations.

In this work, a regression model was applied, which has been developed for a commercial naturally ventilated dairy barn (Hempel et al. 2016) to eliminate the impact of these predictors. Due to comparable geometry and the use for dairy cows, this model seems appropriate. The regression model is based on multilinear regression analysis for air temperature, relative humidity, and wind speed as meteorological predictors, and the day of the year DOY and the time of the day $t$ as predictors for animal activity. The limitations of a regression model can be seen by the model of Hempel et al. (2016). This regression model uses the day of the year as a predictor. This parameter shows a strong cross-correlation to air temperature. The impact of air temperature can be seen in detail in Jeppsson (2002), $\mathrm{Ni}$ (1998), and Smits et al. (1995) for the $\mathrm{NH}_{3}$ release. For the air velocity above the release surface, Ni (1999) showed the importance for the convective mass transfer, which can be parameterized by a power function. A detailed discussion of these predictors can be found in Schauberger et al. (2013). Nevertheless, we used the regression model approach of Hempel et al. (2016) which was developed for a dairy barn in a comparable configuration (364 cows with $70 \mathrm{~m}^{3}$ per animal) with an investigated barn.

A major restriction of the applicability of the regression model is the fact that the model was developed for $\mathrm{NH}_{3}$ and not for $\mathrm{H}_{2} \mathrm{~S}$. Under the assumption that many gaseous emissions from livestock show a similar behavior concerning the predictors, we decided to use this model also for the $\mathrm{H}_{2} \mathrm{~S}$ release as a first educated guess. Alternatively, the emission factors $e$ shown in Table 1 could be used as annual mean values without any modifications related to meteorological parameters and the time of the day and the time of the year.

The annual mean emission factors for 2017 of $\mathrm{NH}_{3}$ and $\mathrm{H}_{2} \mathrm{~S}$, based on the field measurements and the release modification factor $R$, are summarized in Table 2. The annual mean emission factor of $\mathrm{H}_{2} \mathrm{~S}\left(4.24 \mathrm{~g} \mathrm{a}^{-1} \mathrm{AU}^{-1}\right)$ was about 200 times lower than that of $\mathrm{NH}_{3}$. Also in Trabue et al. (2011), $\mathrm{NH}_{3}$ was found to be 2-3 orders of magnitude higher than other gaseous compounds such as trimethylamine, volatile fatty acid, and phenol emitted from a cattle farm. The overall mean emission factor calculated for the tie housing cow building was $0.99 \mathrm{~kg}$ $\mathrm{a}^{-1} \mathrm{AU}^{-1}$ for $\mathrm{NH}_{3}$ in 2017. This value is comparable with the emission rates of dairy farms located in some other countries. Misselbrook et al. (2001) reported that the $\mathrm{NH}_{3}$ emission factor from a dairy cow collecting yard is $1.2 \mathrm{~kg} \mathrm{a}^{-1} \mathrm{AU}^{-1}$ based on concentration measurements with dynamic chambers in England. Also, Mukhtar et al. (2009) reported that $\mathrm{NH}_{3}$ emission factors from free-stall barns and open-lots of a free-stall dairy in central Texas were $1.25 \mathrm{~kg} \mathrm{a}^{-1} \mathrm{AU}^{-1}$ and $1.00 \mathrm{~kg}$ $\mathrm{a}^{-1} \mathrm{AU}^{-1}$, respectively. Baldini et al. (2016) summarized that the $\mathrm{NH}_{3}$ emission factors on a feeding area varied from 
$0.62 \mathrm{~kg} \mathrm{a}^{-1} \mathrm{AU}^{-1}$ (concrete floor) to $2.76 \mathrm{~kg} \mathrm{a}^{-1} \mathrm{AU}^{-1}$ (rubber mat) in dairy farms in Italy. Some researchers (Flesch et al. 2007; Leytem et al. 2011; McGinn et al. 2016) reported high $\mathrm{NH}_{3}$ emission factors for dairy farms (up to $31.0-54.8 \mathrm{~kg} \mathrm{a}^{-1}$ per animal), which were several times higher than the annual mean emission factor given in the present study. The discrepancy in $\mathrm{NH}_{3}$ emission factors might be caused by dietary differences (Leytem et al. 2011; Maasikmets et al. 2015), performance levels, animal activity (loose or cubicle livestock keeping), manure management (scrapper, slatted floor (Philippe et al. 2007a; Philippe et al. 2007b)), indoor climate (temperature, air velocity above the release surface (Schauberger et al. 2013)), and the configuration and operation of the measuring equipment such as flux chambers and wind tunnels (Parker et al. 2013a). For example, direct measurement methods such as the flux chamber may have a limitation on the spatial variability of observations, especially for large area sources. In this case, diffusion models could be used to calculate the concentrations for the validation of the emission rates (Maasikmets et al. 2015).

The release modification factor $R$ of regression models can be used as follows:

(1) To avoid a bias which is caused by the environmental conditions during the measuring campaign;

(2) To model a time series on the basis of the predictors.

For the first case, the measurements in May showed an overestimation for $\mathrm{NH}_{3}$ and $\mathrm{H}_{2} \mathrm{~S}$ by a factor of 4.23 and 8.00 , respectively. For odor emissions from fattening pigs, a factor of 2 (Schauberger et al. 2013) was assessed. To avoid such a bias by the predictors of the release modification factor (meteorological parameters, time of the day, and time of the year), continuous measurements over an entire year have to be undertaken. The result of such time series calculated by the release modification factor has been shown in Fig. 2.

The emission factors were related to the area of the barn, the number of animal places, and the body mass. These are the activity values which are predominantly used to scale the emission to calculate the pollutant emission rate. For a dairy barn with a constant body mass, all activity values can be used. For other livestock keeping systems (e.g., broiler, fattening pigs), the animal growth has to be taken into account.

The biological relevance and the toxicity of $\mathrm{NH}_{3}$ and $\mathrm{H}_{2} \mathrm{~S}$ are well known. In general, the health impact is described by a non-linear dose-response function (Hilderman and Wilson 1999; ten Berge et al. 1986). The health-related exposure $H$ can be calculated by a time series of the ambient concentration $C$ and the exposure time $T$ according to $H \propto C^{\alpha} T$ with an exponent $\alpha$ (Miller et al. 2000) between 1.0 and 3.5 (ten Berge et al. 1986). For the health impact of $\mathrm{NH}_{3}$ and $\mathrm{H}_{2} \mathrm{~S}$, the exponent is assumed as $\alpha=1$. This assumption results in a linear relationship as proposed by EPA (2009). The major benefit of this approach relies on the fact that the annual mean value can be used for health assessments instead of a time series of ambient concentrations, which would be necessary for a non-linear approach $(\alpha>1)$. This means that dispersion model calculations are much more robust for the annual mean compared with the non-linear dose-response relationship.

In the present study, the non-carcinogenic health risk of $\mathrm{H}_{2} \mathrm{~S}$ and $\mathrm{NH}_{3}$ around the dairy farm is very low, practically negligible in view of the methodologies and the acceptable risk levels herein considered. It might be the case that the assessment of individual substances does not show the actual extent of the risk of olfactory annoyances to the population. In our previous study (Wu et al. 2019), the assessment of the odor annoyance from the same dairy farm confirmed a considerable impact.

The cumulative non-carcinogenic risk was herein calculated by the sum of individual $\mathrm{HI}$ of $\mathrm{H}_{2} \mathrm{~S}$ and $\mathrm{NH}_{3}$. This sum generally yields an estimated hazard index for multiple chemicals assessed via a hazard-based approach, and it is valid only for toxics that affect the same target organ or organ system. However, if the individual $\mathrm{HI}$ is greater than 1, it is generally more appropriate to derive separate $\mathrm{HI}$ for each target organ of concern (EPA 2009). For the calculation of noncarcinogenic health risk, the parameters (20 years, 350 days, and $24 \mathrm{~h}$ exposure time) represent a specific type of resident according to the methodology recommended by the EPA (2009). That is, those individuals live and work in the surroundings over that period. Other groups of residents, which are likely to be less exposed to the ambient pollutant concentrations from the farm, have not been taken into account here. For example, a resident that lives in the region but studies/ works away from the source or a resident that works near the source but resides away from it is not taken into account. Farm workers, which on the other hand are likely to be exposed to higher concentrations, have not been considered either. An example of a risk assessment study on human exposure to $\mathrm{H}_{2} \mathrm{~S}$ concentrations near two wastewater treatment plants in Curitiba, Brazil, that has considered different groups, can be found elsewhere (Godoi et al. 2018). Overall, the contour lines show a similar shape as the wind rose, which indicates that the nature of health-related exposure is intimately connected to the meteorology of a particular site (Brancher et al. (2019).

\section{Conclusions}

The emissions as well as the health risk of $\mathrm{NH}_{3}$ and $\mathrm{H}_{2} \mathrm{~S}$ in the context of a dairy farm located in Beijing, China, were evaluated. The results of the flux chamber measurements showed that the emission factors of $\mathrm{NH}_{3}$ were much higher than those of $\mathrm{H}_{2} \mathrm{~S}$. The encompassed area of the contour lines of the ambient concentrations of $\mathrm{NH}_{3}$ was much larger than that of $\mathrm{H}_{2} \mathrm{~S}$, while the contour lines of the health risk of these 
pollutants are similar to each other. Overall, the results suggest that health risks due to ambient concentrations of $\mathrm{NH}_{3}$ and $\mathrm{H}_{2} \mathrm{~S}$ are unlikely to exist for the population living near the dairy farm.

Author contributions Conceptualization, CW, JL, GS, and MP; methodology, FY, MB, CW, CQ, GS; writing - original draft preparation, CW, $\mathrm{MB}, \mathrm{GS}$, and MP; supervision and project administration, JL.

Funding information This work was supported by the National Key R\&D Program of China (nos. 2016YFC0700600 and 2016YFE0115500), the National Natural Science Foundation of China (21906006 and 21878018), and the Interdisciplinary Research Project for Young Teachers of USTB (Fundamental Research Funds for the Central Universities) (no. FRF-IDRY-19-026, TP-17-047A1 and FRF-MP-19012). The cooperation between Austria and China was funded by the OeAD-GmbH (no. CN 10/2016) and the National Key R\&D Program of China (no. 2016YFE0115500). Marlon Brancher is supported by the Austrian Science Fund (FWF) in the framework of the Lise Meitner Programme (project number M 2548-N29).

Data availability The datasets used in the current study are available from the corresponding authors on reasonable request.

\section{Compliance with ethical standards}

Competing interests The authors declare that they have no competing interests.

Open Access This article is licensed under a Creative Commons Attribution 4.0 International License, which permits use, sharing, adaptation, distribution and reproduction in any medium or format, as long as you give appropriate credit to the original author(s) and the source, provide a link to the Creative Commons licence, and indicate if changes were made. The images or other third party material in this article are included in the article's Creative Commons licence, unless indicated otherwise in a credit line to the material. If material is not included in the article's Creative Commons licence and your intended use is not permitted by statutory regulation or exceeds the permitted use, you will need to obtain permission directly from the copyright holder. To view a copy of this licence, visit http://creativecommons.org/licenses/by/4.0/.

\section{References}

Adviento-Borbe M, Wheeler EF, Brown NE, Topper PA, Graves R, Ishler V, Varga G (2010) Ammonia and greenhouse gas flux from manure in freestall barn with dairy cows on precision fed rations. Trans Asabe 53:1251-1266

Arogo J, Westerman PW, Heber AJ (2003) A review of ammonia emissions from confined swine feeding operations. Trans ASAE 46: $805-817$

Baldini C, Borgonovo F, Gardoni D, Guarino M (2016) Comparison among NH3 and GHGs emissive patterns from different housing solutions of dairy farms. Atmos Environ 141:60-66

Bari MA, Kindzierski WB (2017) Concentrations, sources and human health risk of inhalation exposure to air toxics in Edmonton, Canada. Chemosphere 173:160-171

Blanes-Vidal V, Hansen MN, Pedersen S, Rom HB (2008) Emissions of ammonia, methane and nitrous oxide from pig houses and slurry: effects of rooting material, animal activity and ventilation flow. Agric Ecosyst Environ 124:237-244

Brancher M, Griffiths KD, Franco D, de Melo LH (2017) A review of odour impact criteria in selected countries around the world. Chemosphere 168:1531-1570

Brancher M, Piringer M, Grauer AF, Schauberger G (2019) Do odour impact criteria of different jurisdictions ensure analogous separation distances for an equivalent level of protection? J Environ Manag 240:394-403

Brancher M, Knauder W, Piringer M, Schauberger G (2020) Temporal variability in odour emissions: to what extent this matters for the assessment of annoyance using dispersion modelling. Atmos Environ X 5:100054

Cimorelli AJ, Perry SG, Venkatram A, Weil JC, Paine RJ, Wilson RB, Lee RF, Peters WD, Brode RW (2005) AERMOD: a dispersion model for industrial source applications. Part I: general model formulation and boundary layer characterization. J Appl Meteorol 44: 682-693

EPA US (2009) Risk assessment guidance for superfund. Volume I: human health evaluation manual (part F, supplemental guidance for inhalation risk assessment), EPA-540-R-070-002. Office of Superfund Remediation and Technology Innovation Environmental Protection Agency. Available from: https://www. epa.gov/sites/production/files/2015-09/documents/partf_200901_ final.pdf

EPA US (2017) Revision to the Guideline on Air Quality Models: enhancements to the AERMOD dispersion modeling system and incorporation of approaches to address ozone and fine particulate matter. 40 CFR part 51, Appendix W. EPA-HQ-OAR-2015-0310; FRL-9956-23-OAR 2017

EPA US (2018) AERMOD model formulation and evaluation. EPA-454 R-18-003. U.S. Environmental Protection Agency, Research Triangle Park, NC

Feilberg A, Hansen MJ, Liu D, Nyord T (2017) Contribution of livestock $\mathrm{H} 2 \mathrm{~S}$ to total sulfur emissions in a region with intensive animal production. Nat Commun 8:1069

Flesch T, Wilson J, Harper L, Todd R, Cole N (2007) Determining ammonia emissions from a cattle feedlot with an inverse dispersion technique. Agric For Meteorol 144:139-155

Flesch TK, Harper LA, Powell JM, Wilson JD (2009) Inverse-dispersion calculation of ammonia emissions from Wisconsin dairy farms. Trans ASABE 52:253-265

Gallego E, Perales J, Roca F, Guardino X (2014) Surface emission determination of volatile organic compounds (VOC) from a closed industrial waste landfill using a self-designed static flux chamber. Sci Total Environ 470:587-599

GB1455417 (1993) Emission standards for odor pollutants, Beijing, China

Godoi AFL, Grasel AM, Polezer G, Brown A, Potgieter-Vermaak S, Scremim DC, Yamamoto CI, Godoi RHM (2018) Human exposure to hydrogen sulphide concentrations near wastewater treatment plants. Sci Total Environ 610-611:583-590

Hadlocon LJS, Zhao L, Manuzon RB, Elbatawi IE (2014) An acid spray scrubber for recovery of ammonia emissions from a deep-pit swine facility. T Asabe 57:949-960

Hales KE, Parker DB, Cole NA (2012) Potential odorous volatile organic compound emissions from feces and urine from cattle fed cornbased diets with wet distillers grains and solubles. Atmos Environ 60:292-297

Hales K, Parker DB, Cole NA (2015) Volatile organic compound flux from manure of cattle fed diets differing in grain processing method and co-product inclusion. Atmos Environ 100:20-24

Hayes ET, Curran TP, Dodd VA (2006) Odour and ammonia emissions from intensive pig units in Ireland. Bioresour Technol 97:940-948

Hempel S, Saha CK, Fiedler M, Berg W, Hansen C, Amon B, Amon T (2016) Non-linear temperature dependency of ammonia and 
methane emissions from a naturally ventilated dairy barn. Biosyst Eng 145:10-21

Hilderman TL, Wilson DJ (1999) Simulating concentration fluctuation time series with intermittent zero periods and level dependent derivatives. Bound-Layer Meteorol 91:451-482

Hu Y, Cheng H, Tao S (2017) Environmental and human health challenges of industrial livestock and poultry farming in China and their mitigation. Environ Int 107:111-130

Huang D, Guo H (2017) Diurnal and seasonal variations of odor and gas emissions from a naturally ventilated free-stall dairy barn on the Canadian prairies. J Air Waste Manag Assoc 67:1-14

Jaars K, Vestenius M, van Zyl PG, Beukes JP, Hellén H, Vakkari V, Venter M, Josipovic M, Hakola H (2018) Receptor modelling and risk assessment of volatile organic compounds measured at a regional background site in South Africa. Atmos Environ 172:133-148

Jahne MA, Rogers SW, Holsen TM, Grimberg SJ, Ramler IP (2015) Emission and dispersion of bioaerosols from dairy manure application sites: human health risk assessment. Environ Sci Technol 49: 9842-9849

Jeppsson KH (2002) Diurnal variation in ammonia, carbon dioxide and water vapour emission from an uninsulated, deep litter building for growing/finishing pigs. Biosyst Eng 81:213-223

Joo HS, Pius MN, Xiang W, Albert JH, Ji-Qin N, Erin LC, Juan CR-D, Bill WB, Lilong C (2015) Ammonia and hydrogen sulfide concentrations and emissions for naturally ventilated freestall dairy barns. Trans ASABE 58:1321-1331

Keck M (1997) Ammonia emission and odour thresholds of cattle houses with exercise yards. In: Voermans JAM, Monteny GJ (eds) Ammonia and odour emissions from animal production facilities. Proceedings of a International Symposium in Vinkeloord, Netherlands, pp 349-355

Lee S-R, Lee J, Cho S-H, Kim J, Oh J-I, Tsang DCW, Jeong K-H, Kwon EE (2018) Quantification of volatile fatty acids from cattle manure via non-catalytic esterification for odour indication. Sci Total Environ 610-611:992-996

Leytem AB, Dungan RS, Bjorneberg DL, Koehn AC (2011) Emissions of ammonia, methane, carbon dioxide, and nitrous oxide from dairy cattle housing and manure management systems. J Environ Qual 40: 1383-1394

Limpert E, Stahel WA (2011) Problems with using the normal distribution-and ways to improve quality and efficiency of data analysis. PLoS One 6:e21403

Limpert E, Stahel WA, Abbt M (2001) Log-normal distributions across the sciences: keys and clues on the charms of statistics, and how mechanical models resembling gambling machines offer a link to a handy way to characterize log-normal distributions, which can provide deeper insight into variability and probability - normal or lognormal: that is the question. Bioscience 51:341-352

Liu Z, Liu Y, Shi X, Murphy JP, Maghirang R (2017) Variations of ammonia emissions from cattle operations: effects of air temperature and dietary crude protein content. Trans Asabe 60:215-227

Lonsdale CR, Hegarty JD, Cady-Pereira KE, Alvarado MJ, Henze DK, Turner MD, Capps SL, Nowak JB, Neuman JA, Middlebrook AMJAC (2017) Modeling the diurnal variability of agricultural ammonia in Bakersfield, California, during the CalNex campaign. Physics 17:2721-2739

Maasikmets M, Teinemaa E, Kaasik A, Kimmel V (2015) Measurement and analysis of ammonia, hydrogen sulphide and odour emissions from the cattle farming in Estonia. Biosyst Eng 139:48-59

Maasikmets M, Teinemaa E, Kaasik A, Kimmel V (2018) Seasonal variability of the PM and ammonia concentrations in uninsulated loosehousing cowshed. In: Air Quality and Livestock Farming. CRC Press, pp 117-126

McGinn S, Janzen H, Coates T, Beauchemin K, Flesch T (2016) Ammonia emission from a beef cattle feedlot and its local dry deposition and re-emission. J Environ Qual 45:1178-1185
Mikovits C, Zollitsch W, Hörtenhuber SJ, Baumgartner J, Niebuhr K, Piringer M, Anders I, Andre K, Hennig-Pauka I, Schönhart M, Schauberger G (2019) Impacts of global warming on confined livestock systems for growing-fattening pigs: simulation of heat stress for 1981 to 2017 in Central Europe. Int J Biometeorol 63:221-230

Miller FJ, Schlosser PM, Janszen DB (2000) Haber's rule: a special case in a family of curves relating concentration and duration of exposure to a fixed level of response for a given endpoint. Toxicology 149: 21-34

Misselbrook TH, Webb J, Chadwick DR, Ellis S, Pain BF (2001) Gaseous emissions from outdoor concrete yards used by livestock. Atmos Environ 35:5331-5338

Mukhtar S, Mutlu A, Capareda SC, Parnell CB (2008) Seasonal and spatial variations of ammonia emissions from an open-lot dairy operation. J Air Waste Manag Assoc 58:369-376

Mukhtar S, Mutlu A, Lacey RE, Parnell CB Jr (2009) Seasonal ammonia emissions from a free-stall dairy in central Texas. J Air Waste Manag Assoc 59:613-618

Mustafa MF, Liu Y, Duan Z, Guo H, Xu S, Wang H, Lu W (2017) Volatile compounds emission and health risk assessment during composting of organic fraction of municipal solid waste. J Hazard Mater 327:35-43

Ni J (1998) Emission of carbon dioxide and ammonia from mechanically ventilated pig house. K.U. Leuven, Leuven

Ni J (1999) Mechanistic models of ammonia release from liquid manure: a review. J Agric Eng Res 72:1-17

Pandey G, Sharan M (2019) Accountability of wind variability in AERMOD for computing concentrations in low wind conditions. Atmos Environ 202:105-116

Parker D, Ham J, Woodbury B, Cai L, Spiehs M, Rhoades M, Trabue S, Casey K, Todd R, Cole A (2013a) Standardization of flux chamber and wind tunnel flux measurements for quantifying volatile organic compound and ammonia emissions from area sources at animal feeding operations. Atmos Environ 66:72-83

Parker DB, Gilley J, Woodbury B, Kim K-H, Galvin G, Bartelt-Hunt SL, Li X, Snow DD (2013b) Odorous VOC emission following land application of swine manure slurry. Atmos Environ 66:91-100

Perry SG, Cimorelli AJ, Paine RJ, Brode RW, Weil JC, Venkatram A, Wilson RB, Lee RF, Peters WD (2005) AERMOD: a dispersion model for industrial source applications. Part II: model performance against 17 field study databases. J Appl Meteorol 44:694-708

Philippe F-X, Laitat M, Canart B, Vandenheede M, Nicks BJA (2007a) Gaseous emissions during the fattening of pigs kept either on fully slatted floors or on straw flow. 1: 1515-1523

Philippe F-X, Laitat M, Canart B, Vandenheede M, Nicks BJLS (2007b) Comparison of ammonia and greenhouse gas emissions during the fattening of pigs, kept either on fully slatted floor or on deep litter. 111: $144-152$

Prata AA, Santos JM, Beghi SP, Fernandes IF, Vom Marttens LLC, Pereira Neto LI, Martins RS, Reis NC, Stuetz RM (2016) Dynamic flux chamber measurements of hydrogen sulfide emission rate from a quiescent surface-a computational evaluation. Chemosphere 146:426-434

Qian W, Venkatram A (2011) Performance of steady-state dispersion models under low wind-speed conditions. Bound-Layer Meteorol $138: 475-491$

Rørvang MV, Jensen MB, Nielsen BL (2017) Development of test for determining olfactory investigation of complex odours in cattle. Appl Anim Behav Sci 196:84-90

Saha CK, Ammon C, Berg W, Loebsin C, Fiedler M, Brunsch R, von Bobrutzki K (2013) The effect of external wind speed and direction on sampling point concentrations, air change rate and emissions from a naturally ventilated dairy building. Biosyst Eng 114:267-278

Saha C, Ammon C, Berg W, Fiedler M, Loebsin C, Sanftleben P, Brunsch R, Amon T (2014) Seasonal and diel variations of ammonia and methane emissions from a naturally ventilated dairy building 
and the associated factors influencing emissions. Sci Total Environ 468:53-62

Schauberger G, Piringer M, Petz E (2000) Steady-state balance model to calculate the indoor climate of livestock buildings, demonstrated for fattening pigs. Int J Biometeorol 43:154-162

Schauberger G, Schmitzer R, Kamp M, Sowa A, Koch R, Eckhof W, Eichler F, Grimm E, Kypke J, Hartung E (2012) Empirical model derived from dispersion calculations to determine separation distances between livestock buildings and residential areas to avoid odour nuisance. Atmos Environ 46:508-515

Schauberger G, Lim TT, Ni JQ, Bundy DS, Haymore BL, Diehl CA, Duggirala RK, Heber AJ (2013) Empirical model of odor emission from deep-pit swine finishing barns to derive a standardized odor emission factor. Atmos Environ 66:84-90

Smits MCJ, Valk H, Elzing A, Keen A (1995) Effect of protein nutrition on ammonia emission from a cubicle house for dairy cattle. Livest Prod Sci 44:147-156

ten Berge WF, Zwart A, Appelman LM (1986) Concentration-time mortality response relationship of irritant and systemically acting vapours and gases. J Hazard Mater 13:301-309

Trabue S, Scoggin K, McConnell L, Maghirang R, Razote E, Hatfield J (2011) Identifying and tracking key odorants from cattle feedlots. Atmos Environ 45:4243-4251

Wang Y, Li X, Yang J, Tian Z, Sun Q, Xue W, Dong H (2018) Mitigating greenhouse gas and ammonia emissions from beef cattle feedlot production: a system meta-analysis. Environ Sci Technol 52: $11232-11242$
Wu W, Zhang G, Kai P (2012) Ammonia and methane emissions from two naturally ventilated dairy cattle buildings and the influence of climatic factors on ammonia emissions. Atmos Environ 61:232-243

Wu C, Liu J, Zhao P, Li W, Yan L, Piringer M, Schauberger G (2017) Evaluation of the chemical composition and correlation between the calculated and measured odour concentration of odorous gases from a landfill in Beijing, China. Atmos Environ 164:337-347

Wu C, Liu J, Liu S, Li W, Yan L, Shu M, Zhao P, Zhou P, Cao W (2018) Assessment of the health risks and odor concentration of volatile compounds from a municipal solid waste landfill in China. Chemosphere 202:1-8

Wu CD, Brancher M, Yang F, Liu JM, Qu C, Schauberger G, Piringer M (2019) A comparative analysis of methods for determining odourrelated separation distances around a dairy farm in Beijing, China. Atmosphere 10:231

Yang Y, Liao W, Wang X, Liu C, Xie Q, Gao Z, Ma W, He YJA (2016) Quantification of ammonia emissions from dairy and beef feedlots in the Jing-Jin-Ji district, China. Ecosyst Environ 232:29-37

Ye Z, Zhu S, Kai P, Li B, Blanes-Vidal V, Pan J, Wang C, Zhang G (2011) Key factors driving ammonia emissions from a pig house slurry pit. Biosyst Eng 108:195-203

Publisher's note Springer Nature remains neutral with regard to jurisdictional claims in published maps and institutional affiliations. 